\title{
The Frequency of Natural Killer Cell Subsets in Patients with Acquired Immune Deficiency Syndrome with Deep Fungal Infections
}

This article was published in the following Dove Press journal: Infection and Drug Resistance

\section{Gao Chen (1) \\ Chun-Jun Qin \\ Meng-Zheng Wu \\ Fei-Fei Liu \\ Shu-Shu Liu \\ Li Liu}

Department of Infectious Diseases, People's Hospital of Deyang City, Deyang, 618000, People's Republic of China
Correspondence: Gao Chen Department of Infectious Diseases, People's Hospital of Deyang City, No. 173 of Sec. I, Taishan North Road, Jingyang District, Deyang, 618000, People's

Republic of China

$\mathrm{Tel} / \mathrm{Fax}+868382418631$

Email chenchen99_dr@163.com
Objective: This study aimed to investigate the expression of natural killer (NK) cell subsets in patients with acquired immune deficiency syndrome (AIDS) and deep fungal infections and the significance of such expression.

Methods: A total of 829 patients with AIDS, who were treated in People's Hospital of Deyang City our hospital between January 2011 and March 2019, were enrolled in the study. They were divided into two groups: those with human immunodeficiency virus (HIV) and invasive fungal infection (IFI) (HIV + IFI) $(\mathrm{n}=390)$ and those with HIV and no IFI (HIV + non-IFI) $(n=439)$. Another 200 healthy volunteers were enrolled as the control group. The numbers of NK cell subsets in each group were compared.

Results: The level of NK cells, number of NK cells in all lymphocytes, proportions of CD56 ${ }^{\text {bright }}, \mathrm{CD}^{2} 6^{\mathrm{dim}}$, and CD56 $6^{\mathrm{dim}} \mathrm{NK}$ cells in NK cells, and the level of CD56 $6^{-} \mathrm{CD} 16^{+} \mathrm{NK}$ cells were significantly lower in the HIV + IFI group than in the HIV + non-IFI group and control group $(P<0.05)$. Moreover, $\mathrm{CD}^{+} \mathrm{T}, \mathrm{CD}^{+} / \mathrm{CD}^{+}$, and $\mathrm{NK}$ cells were negatively correlated with HIV-RNA expression $(P<0.05)$.

Conclusion: A combination of AIDS and deep fungal infection can change the immune status of a patient. This condition can be diagnosed early through the detection of NK cell expression.

Keywords: natural killer cells, AIDS, deep fungal infection, CD56, expression

\section{Introduction}

Human immunodeficiency virus (HIV) is the pathogen of acquired immune deficiency syndrome (AIDS). ${ }^{1}$ Patients with this disease have a low cellular immune function; as such, they experience frequent complications, including various opportunistic infections, of which fungal infection is the most common. In recent years, the incidence rate of AIDS and fungal infection has increased. ${ }^{2}$ Because patients with AIDS do not have immune systems that are capable of fighting infections, ${ }^{3,4}$ it is important to prevent deep fungal infection.

Natural killer $(\mathrm{NK})$ cells are immune cells that play a crucial role in antiinfection, anti-tumor, and hemopoietic regulation. ${ }^{5}$ Some studies have confirmed that these cells also serve an important function in patients with AIDS and deep fungal infections, ${ }^{6}$ but their exact significance has yet to be further explored. An animal experiment revealed that mice without functional NK cell subsets are more susceptible to fungal infections than mice with normal NK cell subsets. ${ }^{7}$ The present study found that the levels of white blood cells, lymphocytes, CD4+ 
$\mathrm{T}$ cells, and CD8+ T cells, the ratio of CD4+/CD8+ cells, and the total number of NK cells in patients with AIDS and deep fungal infections were significantly lower in the human immunodeficiency virus (HIV) + IFI group than in the HIV + non-IFI and control groups. These results suggest that the decreased number of NK cells in patients with AIDS and deep fungal infections is related to a change in immune status.

In this study, the expression of NK cell subsets in patients with AIDS and deep fungal infections was observed and the significance of this expression was explored to provide a basis for the clinical treatment of AIDS.

\section{Data and Methods Study Sample}

A total of 829 patients with AIDS, who were treated in People's Hospital of Deyang City between January 2011 and March 2019, were enrolled in this study. Of these patients, 390 had deep fungal infections and were assigned to the HIV + invasive fungal infection (IFI) group (HIV + IFI); the remaining 439 did not have fungal infections and were assigned to the HIV + non-IFI group (HIV + non-IFI) were enrolled as the control group.

The inclusion criteria for the study subjects were as follows: (1) patients who met the AIDS diagnosis standard; ${ }^{8}$ (2) patients aged 18-65 years; (3) patients who participated in the survey voluntarily and gave informed consent. The exclusion criteria were as follows:

(1) patients with serious immune diseases other than AIDS; (2) patients with severe diseases of the heart, brain, or kidney, or one or more other severe diseases;

(3) patients with mental health disorders.

The study was conducted in accordance with the Declaration of Helsinki (2013 revision) and was approved by the Ethics Committee of the People's Hospital of Deyang City. A written consent was obtained from all the patients and healthy volunteers.

\section{Methods}

A total of $6 \mathrm{~mL}$ of venous blood was collected from each participant and then centrifuged at $3000 \mathrm{r} / \mathrm{min}$ for 15 minutes. The serum was then separated and preserved in a refrigerator at $-80^{\circ} \mathrm{C}$ for testing. The level of HIV-1RNA was detected using a real-time fluorescence quantitative polymerase chain reaction machine. $\mathrm{T}$ cell subsets were detected using a Beckman Coulter FC500 fully automatic flow cytometer.

Flow cytometry was used to determine the content of NK cells and their cell subsets in the peripheral blood of the three groups: $1 \mathrm{~mL}$ of peripheral blood was taken from all the subjects, and heparin sodium was used for anticoagulation; the content was determined within 4 hours at room temperature. The percentages of total NK cells, CD56 ${ }^{\text {bright }} \mathrm{NK}$ cells, CD56 ${ }^{\mathrm{dim}} \mathrm{NK}$ cells and $\mathrm{CD}^{-} 6^{-} \mathrm{CD} 16^{+} \mathrm{NK}$ cells in the peripheral blood lymphocytes were determined by whole-blood direct immunofluorescence staining. (Kits from Becton, Dickinson and Company, BD Biosciences. Agent: Bidi Medical Device (Shanghai) Co., Ltd.)

The content of $\mathrm{CD}^{+} 3, \mathrm{CD}^{+} 4$, and $\mathrm{CD}^{+} 8 \mathrm{~T}$ lymphocyte subsets in the three groups were determined by flow cytometry: $200 \mathrm{~L}$ of hemolysin was added to 1800 $\mathrm{L}$ aseptic injection water for use. After adding $100 \mathrm{~mL}$ peripheral blood to each test tube, 1 reagent and 2 reagents were added accordingly and mixed at a low speed. The test tubes were placed at room temperature and stored in darkness for 20 minutes. A total of $1000 \mathrm{~L}$ of the prepared hemolysin was then added to each test tube and mixed at a low speed. The test tubes were stored in darkness at room temperature before being placed in a low-temperature, high-speed centrifuge and centrifuged at $1500 \mathrm{r} / \mathrm{min}$ for 5 minutes. The lower layer retained about $50 \mathrm{~L}$ of residual liquid. A total of $2 \mathrm{~mL}$ washing liquid was added to the test tubes, which were then centrifuged in a low-temperature, high-speed centrifuge at $1500 \mathrm{r} / \mathrm{min}$ for 5 minutes. The bottom residual liquid remained at about $50 \mathrm{~L}$. Finally, $400 \mathrm{~L}$ of sheath fluid was added and determined by the machine. (Kits from Becton, Dickinson and Company, BD Biosciences. Agent: Bidi Medical Device (Shanghai) Co., Ltd.)

\section{Statistical Analysis}

The data were processed using the SPSS 18.0 software package. Measurement data were expressed as mean \pm standard deviation. A multigroup comparison was conducted using univariate analysis of variance, and an intergroup pairwise comparison was conducted using the least significant difference $t$ test (variables with homogeneity of variance) or the Dunnett T3 test (variables with heterogeneity of variance). Count data were expressed as rates, which were compared using the $\chi^{2}$ test. Multivariate logistic stepwise regression analysis was used to analyze the 
Table I Comparison of Basic Information and Blood Tests Among the Three Groups $(\bar{\chi} \pm s)$

\begin{tabular}{|c|c|c|c|c|c|}
\hline Index & $\begin{array}{l}\text { HIV + IFI Group } \\
(n=390)\end{array}$ & $\begin{array}{l}\text { HIV+Non-IFI Group } \\
(n=439)\end{array}$ & $\begin{array}{l}\text { Control Group } \\
(n=200)\end{array}$ & $\begin{array}{l}\text { Statistical } \\
\text { Value }\end{array}$ & $P$ value \\
\hline Male/female & $300 / 90$ & $332 / 107$ & $160 / 40$ & 1.483 & 0.476 \\
\hline Age & $36.12 \pm 11.56$ & $35.34 \pm 11.58$ & $36.89 \pm 11.63$ & 3.015 & 0.072 \\
\hline HIV RNA (log10 copies/mL) & $5.94 \pm 2.69$ & $5.28 \pm 1.96$ & Undetectable & 2.871 & 0.282 \\
\hline Leucocyte (I/L) & $4259 \pm 176.46$ & $5832 \pm 173.48$ & $6012 \pm 174.32$ & 5428.28 & $<0.0001$ \\
\hline Lymphocyte $(I / \mu \mathrm{L})$ & $589.76 \pm 67.65$ & $1986.87 \pm 95.42$ & $2196 \pm 100.12$ & $17,549.48$ & $<0.0001$ \\
\hline $\mathrm{CD}^{+} \mathrm{T}$ cells $(\mathrm{I} / \mu \mathrm{L})$ & $13.24 \pm 7.13$ & $402.57 \pm 42.43$ & $748.23 \pm 102.35$ & 134.03 & $<0.0001$ \\
\hline $\begin{array}{l}\text { Proportion of } C D 4^{+} T \text { cells in total } \\
\text { lymphocytes (\%) }\end{array}$ & $2.15 \pm 1.43$ & $22.79 \pm 6.38$ & $36.78 \pm 6.89$ & 43.08 & $<0.0001$ \\
\hline $\mathrm{CD8}^{+} \mathrm{T}$ cells $(\mathrm{I} / \mu \mathrm{L})$ & $299.15 \pm 33.74$ & $690.54 \pm 64.99$ & $622.56 \pm 203.48$ & 69.58 & $<0.0001$ \\
\hline $\begin{array}{l}\text { Proportion of } C D 8^{+} T \text { cells in total } \\
\text { lymphocytes (\%) }\end{array}$ & $59.18 \pm 14.98$ & $37.47 \pm 9.46$ & $28.92 \pm 8.82$ & 19.02 & $<0.0001$ \\
\hline $\mathrm{CD}^{+} \mathrm{T}$ cells $/ \mathrm{CD}^{+}{ }^{+} \mathrm{T}$ cells & $0.04 \pm 0.02$ & $0.7 I \pm 0.06$ & $1.14 \pm 0.36$ & 160.14 & $<0.0001$ \\
\hline
\end{tabular}

correlation of T cell subsets and NK cell subsets with HIV1RNA. $P<0.05$ was considered statistically significant.

\section{Results}

\section{Clinical Characteristics of the Participants}

In the HIV + IFI group $(\mathrm{n}=390)$, all participants had stage III or stage IV AIDS. This group consisted of 28 patients from the Jingyang District of Deyang City, 119 from Zhongjiang County, 58 from the Luojiang District, 49 from Mianzhu City, 37 from Guanghan City, 28 from Shifang City, and 71 from areas outside Deyang City. In this group, 286 patients were given tenofovir and lamivudine according to the plan of antiviral, 93 were given tenofovir, lamivudine, and g set cheese antiviral treatment, and 11 were given jie fu kang (aikoen c) antiviral treatment. Pneumocystis carinii pneumonia (PCP) occurred in 101 cases, lymphoma and Kaposi's sarcoma in 15 cases, respiratory failure in 105 cases, tuberculosis (TB) or extrapulmonary tuberculosis in 132 cases, diabetes in 122 cases, and high blood pressure in 107 cases.

In the HIV + non-IFI group $(\mathrm{n}=439)$, all participants had stage III or stage IV AIDS. The group consisted of 35 patients from the Jingyang District, Deyang City, 118 from Zhongjiang County, 62 from the Luojiang District, 56 from Mianzhu City, 39 from Guanghan City, 47 from Shifang City, and 82 from areas outside Deyang City. In this group, 327 patients were given tenofovir and lamivudine according to the plan of antiviral, 88 were given tenofovir, lamivudine, and $\mathrm{g}$ set cheese antiviral treatment, and 24 were given jie fu kang (aikoen c) for antiviral treatment. PCP occurred in 126 cases, lymphoma and Kaposi's sarcoma in 22 cases, respiratory failure in 153 cases, pulmonary tuberculosis in 188 cases, diabetes in 215 cases, and high blood pressure in 174 cases.

\section{Comparison of Blood Examinations Between the Three Groups}

Of the 390 patients in the HIV + IFI group, 300 were male and 90 were female, with an age range of 26-54 years (mean age $=36.12 \pm 11.56$ years). Of the 439 patients in the HIV + non-IFI group, 332 were male and 107 were female, with an age range of $25-53$ years (mean age $=$ $35.34 \pm 11.58$ years). Of the 200 volunteers in the control group, 160 were male and 40 were female, with an age range of 24-56 years (mean age $=36.89 \pm 11.63$ years). The differences in general data between the groups, such as gender $\left(\chi^{2}=1.483, \mathrm{P}=0.476\right)$ and age $(\mathrm{t}=3.015, \mathrm{P}=$ 0.072 ), were not statistically significant; hence, the three groups were comparable (Table 1, Figure 1).

\section{Distribution of NK Cell Subsets Between the Three Groups}

In the HIV + IFI group, the level of NK cells, proportion of NK cells in all lymphocytes, proportions of CD56 $6^{\text {bright }} \mathrm{NK}$, 
A

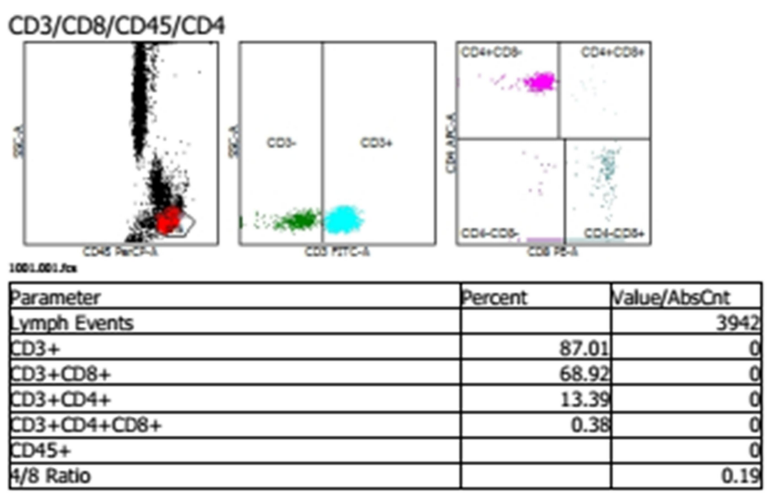

QC Messages

Manual Gate is in effect.

\% T-Sum is: 4.69

4/8 ratio is: 0.19

Comments
B

CD3/CDe/CD45/CD4
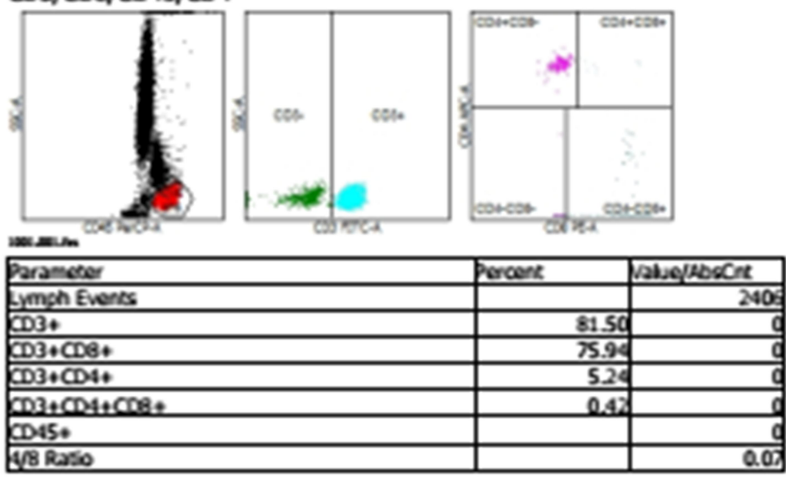

QC Messages

Man-al Cote is in cffoct.

\% T.Sum is: 0.33

48 rath is: 0.00

Comments

\section{C} $\mathrm{CD} 3 / \mathrm{CD} 8 / \mathrm{CD} 45 / C D 4$

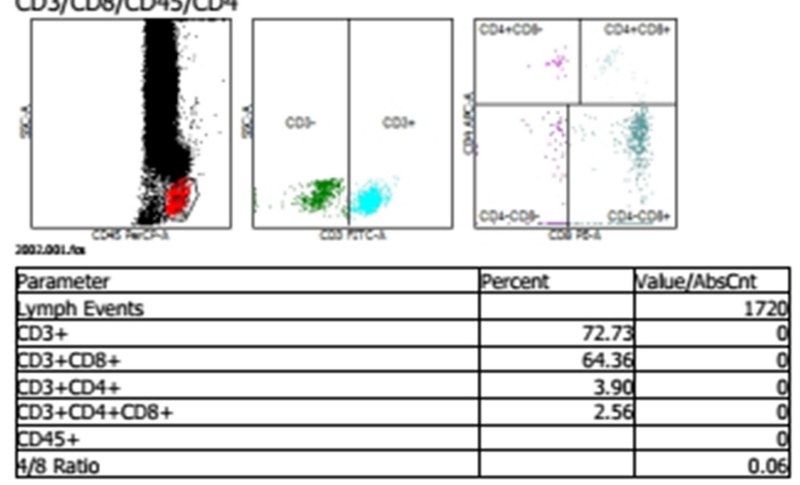

QC Messages

Less than 2500 lymphocytes collected

Could not acquire the user-requested number of lymphocytes.

\% T-Sum is: 4.48

$4 / 8$ ratio is: 0.06

Comments

Figure I Flow cytometry results (A-C).

CD56 ${ }^{\mathrm{dim}} \mathrm{NK}$, cells in the NK cells, and the level of CD56 ${ }^{-} \mathrm{CD} 16^{+} \mathrm{NK}$ cells were significantly lower than in the HIV + non-IFI group and control group $(P<0.05)$ (see Table 2). Furthermore, the proportion of CD56 ${ }^{\text {bright }}$ NK cells in the NK cells and the proportion of $\mathrm{CD} 56^{-} \mathrm{CD} 16^{+} \mathrm{NK}$ cells in the NK cells were significantly higher than those in the $\mathrm{HIV}+$ non-IFI and healthy control groups $(P<0.05)$.

\section{Analysis of the Correlation Between T Cell and NK Cell Subset Distribution and HIV-RNA Expression}

Multivariate logistic analysis was carried out and revealed that there was a significant negative correlation between
HIV-RNA expression and $\mathrm{CD} 4^{+} \mathrm{T}, \mathrm{CD}^{+} / \mathrm{CD}^{+}$, and $\mathrm{NK}$ cells $(P<0.05)$. However, there was no significant correlation between HIV-RNA expression and $\mathrm{CD}^{+} \mathrm{T}$, CD56 ${ }^{\text {bright }} \mathrm{NK}, \mathrm{CD}^{\mathrm{dim}} \mathrm{NK}$, or $\mathrm{CD} 56^{-} \mathrm{CD} 16^{+} \mathrm{NK}$ cells $(P>0.05)$ (see Table 3).

\section{Opportunistic Infections}

In the HIV + IFI group, there were 232 cases of deep pulmonary fungal infection, 68 cases of urinary tract deep fungal infection, 27 cases of deep fungal bloodstream infection, and 63 cases of deep abdominal and other viscera fungal infection. Candida albicans was the most common pathogenic bacterium, occurring in 243 cases. There were also 20 cases of tropical candida, 19 
Table 2 Distribution of NK Cell Subsets in Three Groups of Patients $(\bar{\chi} \pm s)$

\begin{tabular}{|c|c|c|c|c|c|}
\hline Index & $\begin{array}{l}\text { HIV + IFI Group } \\
(n=390)\end{array}$ & $\begin{array}{l}\text { HIV+Non-IFI Group } \\
(n=439)\end{array}$ & $\begin{array}{l}\text { Control Group } \\
(n=200)\end{array}$ & $\begin{array}{l}\text { Statistical } \\
\text { Value }\end{array}$ & $P$ value \\
\hline NK cells $(I / \mu L)$ & $88.56 \pm 17.32$ & $330.12 \pm 30.12$ & $319.65 \pm 28.56$ & 5479.13 & $<0.000$ I \\
\hline $\begin{array}{l}\text { Proportion of NK cells in total } \\
\text { lymphocytes (\%) }\end{array}$ & $13.12 \pm 4.98$ & $17.02 \pm 6.57$ & $14.34 \pm 3.57$ & 28.15 & $<0.000$ I \\
\hline CD56 $6^{\text {bright }} \mathrm{NKcells}(\mathrm{I} / \mu \mathrm{L})$ & $4.45 \pm 1.56$ & $12.23 \pm 4.58$ & $13.23 \pm 3.58$ & 298.68 & $<0.0001$ \\
\hline $\begin{array}{l}\text { Proportion of CD } 56^{\text {bright }} \mathrm{NKcells} \text { in NK } \\
\text { cells (\%) }\end{array}$ & $5.32 \pm 1.41$ & $4.45 \pm 1.45$ & $4.02 \pm 1.32$ & 30.53 & 0.001 \\
\hline CD56 ${ }^{\mathrm{dim}} \mathrm{NKcells}(\mathrm{I} / \mu \mathrm{L})$ & $37.13 \pm 10.60$ & $227.32 \pm 50.61$ & $253.37 \pm 11.60$ & 998.72 & $<0.0001$ \\
\hline $\begin{array}{l}\text { Proportion of CD } 56^{\mathrm{dim}} \mathrm{NK} \text { cells in NK } \\
\text { cells (\%) }\end{array}$ & $65.23 \pm 5.41$ & $82.03 \pm 8.31$ & $79.32 \pm 3.61$ & 543.73 & $<0.0001$ \\
\hline CD56 ${ }^{-} \mathrm{CD} 16^{+} \mathrm{NK}$ cells $(\mathrm{I} / \mu \mathrm{L})$ & $25.76 \pm 8.97$ & $43.12 \pm 9.62$ & $51.12 \pm 8.62$ & 265.53 & $<0.0001$ \\
\hline $\begin{array}{l}\text { Proportion of } \mathrm{CD} 56^{-} \mathrm{CDI} 6^{+} \mathrm{NK} \text { cells in } \\
\text { NK cells (\%) }\end{array}$ & $33.12 \pm 7.63$ & $15.52 \pm 3.44$ & $15.78 \pm 4.74$ & 537.68 & $<0.0001$ \\
\hline
\end{tabular}

Table 3 Analysis of the Correlation Between T Cell and NK Cell Subset Distribution and HIV-RNA Expression

\begin{tabular}{|c|c|c|c|c|c|c|c|c|c|}
\hline Cell Subset & B & SE & Wald & OR & Value & $95 \% \mathrm{Cl}$ & $p$-value & $\begin{array}{l}\text { HIV + IFI Group } \\
(n=390)\end{array}$ & $\begin{array}{l}\text { HIV+Non-IFI } \\
\text { Group } \\
(n=439)\end{array}$ \\
\hline \multicolumn{10}{|l|}{$\begin{array}{l}\text { Control Group } \\
(n=200)\end{array}$} \\
\hline $\mathrm{CD}^{+}{ }^{+} \mathrm{T}$ cell & -0.288 & 0.104 & 4.697 & 0.624 & $0.602 \sim 0.629$ & 0.018 & $13.24 \pm 7.13$ & $402.57 \pm 42.43$ & $748.23 \pm 102.35$ \\
\hline $\mathrm{CD8}^{+} \mathrm{T}$ cell & 0.104 & 0.619 & 1.579 & 0.134 & $0.009 \sim 1.995$ & 0.155 & $299.15 \pm 33.74$ & $690.54 \pm 64.99$ & $622.56 \pm 203.48$ \\
\hline $\begin{array}{l}\mathrm{CD}^{+} \mathrm{T} \text { cell/ } \\
\mathrm{CD} 8^{+} \mathrm{T} \text { cell }\end{array}$ & -0.378 & 0.115 & 1.246 & 0.675 & $0.643 \sim 0.709$ & 0.001 & & & \\
\hline CD56 $6^{\text {bright }} \mathrm{NK}$ cell & -0.147 & 0.776 & 1.89 & 0.142 & $0.015 \sim 1.344$ & 0.086 & $4.45 \pm 1.56$ & $12.23 \pm 4.58$ & $13.23 \pm 3.58$ \\
\hline CD56 ${ }^{\mathrm{dim}} \mathrm{NK}$ cell & -0.363 & 0.113 & 4.479 & 0.362 & $0.303 \sim 0.4 \mathrm{II}$ & $0.35 I$ & $37.13 \pm 10.60$ & $227.32 \pm 50.61$ & $253.37 \pm 11.60$ \\
\hline $\begin{array}{l}\mathrm{CD} 56^{-} \mathrm{CD} / 6^{+} \mathrm{NK} \\
\text { cell }\end{array}$ & -0.195 & 0.617 & 1.352 & 0.371 & $0.105 \sim 1.299$ & 0.122 & $25.76 \pm 8.97$ & $43.12 \pm 9.62$ & $51.12 \pm 8.62$ \\
\hline NK cell & -0.372 & 0.107 & 4.866 & 0.683 & $0.492 \sim 0.973$ & 0.037 & $88.56 \pm 17.32$ & $330.12 \pm 30.12$ & $319.65 \pm 28.56$ \\
\hline
\end{tabular}

cases of smooth candida, 44 cases of Cryptococcus, 49 cases of Aspergillus, 7 cases of Penicillium marneffei and 8 cases of histoplasmosis.

\section{Discussion}

Opportunistic infection is the most frequent cause of death in patients with AIDS due to their low cellular immune function. ${ }^{9,10}$ Of the many types of infection, deep fungal infection is the most common in patients with AIDS. Fungi can invade the skin, viscera, and deep tissues of the body, which may cause the systemic spread of infection. There are many issues that can accompany antifungal treatment for patients with AIDS and deep fungal infections, such as drug resistance and ineffective treatment. $^{11,12}$ Therefore, the early detection of deep fungal infections in patients with AIDS is of great 
significance to improving and prolonging the lives of these patients.

NK cells are one of the most important effector cells for the treatment of deep fungal infections in patients with AIDS because they produce cytokines and chemokines through their cytotoxic function. ${ }^{13}$ NK cells serve as crucial lymphocytes in the inherent immune system; there is no need for pre-sensitization to exert their function of immune defense, and they can induce and regulate acquired immune function by secreting cytokines. ${ }^{14}$ A related study revealed that the level of NK cells in patients with AIDS is lower than that of healthy individuals. $^{15}$

NK cells primarily express CD16 and CD56 molecules and are divided into two subsets according to the different expression densities of CD56 molecules on the membrane surface: CD56bright NK cells and CD56dim NK cells. The former are immunomodulatory NK cells, the killing ability of which is low, while the latter are NK cells with killer properties that can secrete an appropriate number of cytokines. ${ }^{16} \mathrm{NK}$ cells are mainly comprised of CD56dim CD16+ NK cells; CD56bright NK cells only account for approximately $10 \%$. The present study found that the level of NK cells, proportion of NK cells in all lymphocytes, levels of CD56bright and CD56dim NK cells, proportion of CD56dim NK cells in the NK cells, and level of CD56CD16+ NK cells were significantly lower in the HIV + IFI group than in the HIV + non-IFI and control groups. In addition, the proportions of CD56bright and CD56-CD16 + NK cells in the NK cells were significantly higher in the $\mathrm{HIV}+\mathrm{IFI}$ group than in the HIV + non-IFI and healthy control groups. This confirms that the number and function of NK cells were decreased in patients with AIDS and deep fungal infections, which suggests that the loss of number and function of NK cells in patients with AIDS is an important factor for fungal infections; this could be due to the fact that AIDS can destroy NK cells. The study also found that the number of CD4+ T cells and NK cells and the $\mathrm{CD} 4+/ \mathrm{CD} 8+$ ratio were significantly negatively correlated with HIV-RNA expression, while the number of CD8+ T, CD56bright NK, CD56dim NK, and CD56CD16+ NK cells were not significantly correlated with HIV-RNA expression. These results further suggest that the function of NK cells could be the key factor in maintaining normal levels of CD4+ $\mathrm{T}$ cells and inhibiting virus replication.

Limitations of this study are that our results are simply a measurement of the size of cell subsets, and do not contain functional analyses; further work on NK cell subsets and aberrant function during HIV, and during fungal infections, are needed.

\section{Conclusion}

A combination of AIDS and deep fungal infections can change the immune status of patients. The early clinical diagnosis of this condition can be achieved by detecting the expression of NK cell subsets, and antibacterial treatment should be implemented early.

\section{Acknowledgments}

We are particularly grateful to all the people who have given us help on our article.

\section{Disclosure}

The authors declare that they have no competing interests.

\section{References}

1. de Mendoza C. UNAIDS update global HIV numbers. AIDS Rev. 2019;21(3):170-171.

2. Horn CA, Washburn RG. Anticryptococcal activity of NK cell-enriched peripheral blood lymphocytes from human immunodeficiency virus-infected subjects: responses to interleukin-2, interferon-gamma, and interleukin-12. J Infect Dis. 1995;172 (4):1023-1027. doi:10.1093/infdis/172.4.1023

3. Li SS, Ogbomo H, Mansour MK, et al. Identification of the fungal ligand triggering cytotoxic PRR-mediated NK cell killing of Cryptococcus and Candida. Nat Commun. 2018;9(1):751. doi:10.1038/s41467-018-03014-4

4. $\mathrm{Xu} \mathrm{CJ}, \mathrm{Hu} \mathrm{ZL}$, Wei $\mathrm{HX}$, et al. Magnetic resonance imaging features of cryptococcal infection of the central nervous system in AIDS patients. J Cent South Univ. 2017;42(10):1184-1190.

5. O'Brien KL, Finlay DK. Immunometabolism and natural killer cell responses. Nat Rev Immunol. 2019;19(5):282-290. doi:10.1038/ s41577-019-0139-2

6. Liu LJ, Zhao M, Zheng LP, et al. Analysis of NK cell subpopulation distribution and cytokine expression in AIDS patients with fungal infection. J Mod Integr Chin West Med. 2017;26(36):4002-4005.

7. Hua Y, Deng WZ, Wang CL, et al. Effects of Oyster polysaccharide on blood immunoglobulin, $\mathrm{T}$ lymphocyte subset, natural killer cell and natural killer T lymphocyte in exhausted exercise mice. Chin J Rehabil Med. 2014;29(06):571-573.

8. Guo XB. Diagnosis of HIV infection and AIDS. Foreign Med. 1995;02:61-63.

9. Lionakis MS, Levitz SM. Host control of fungal infections: lessons from basic studies and human Cohorts. Annu Rev Immunol. 2018;36:157-191. doi:10.1146/annurev-immunol-042617-053318

10. Mao NL, Wu DR, Guo WG, et al. Analysis of CD4 +T lymphocyte count and HIV viral load in 2010-2013 in Beihai City. Chin J Dis Control. 2015;19(04):424-425+428.

11. Jing N, Zhang JC, Yang YL, et al. Short-term clinical efficacy of natural killer cells in the treatment of advanced liver cancer. Chin J Tumor Biother. 2016;23(04):515-518.

12. Sharma H, Sudharshan S, Therese L, Agarwal M, Biswas J. Candida albicans scleral abscess in a HIV-positive patient and its successful resolution with antifungal therapy-a first case report. J Ophthalmic Inflamm Infect. 2016;6(1):24. doi:10.1186/s12348-016-0092-1 
13. Zhang M, Yang LS, Peng DZ, et al. Changes and significance of different immune status of chronic HBV infection and peripheral blood T, B cell subsets and NK cells in liver cirrhosis. J Pract Med. 2014;30(20):3233-3236.

14. Ji JL, Li TM. The proportion of natural killer cells and CD3 -CD56 -CD16 (Bright) subgroup in peripheral blood of neonatal bacterial pneumonia patients was decreased. $J$ Cell Mol Immunol. 2016;32(10):1390-1392+1395.
15. Giacomazzi J, Baethgen L, Carneiro LC, et al. The burden of serious human fungal infections in Brazil. Mycoses. 2016;59(3):145-150. doi:10.1111/myc. 12427

16. Zhai XJ, Ni M, Wang Z. Effect of laryngeal mask Insertion on perioperative $\mathrm{T}$ lymphocyte subsets and natural killer cells in patients undergoing radical mastectomy. Chin $J$ Gerontol. 2014;34 (12):3268-3269.

\section{Publish your work in this journal}

Infection and Drug Resistance is an international, peer-reviewed openaccess journal that focuses on the optimal treatment of infection (bacterial, fungal and viral) and the development and institution of preventive strategies to minimize the development and spread of resistance. The journal is specifically concerned with the epidemiology of antibiotic resistance and the mechanisms of resistance development and diffusion in both hospitals and the community. The manuscript management system is completely online and includes a very quick and fair peerreview system, which is all easy to use. Visit http://www.dovepress.com/ testimonials.php to read real quotes from published authors. 